\title{
機械式制御によるアクティブ免震装置の開発 （コンセプトの提案，実証実験，およびパラメータスタディ）
}

\author{
青木 保夫 ${ }^{* 1}$ ，平松 晃典 ${ }^{* 2}$ ，和地 天平 ${ }^{* 2}$ ，青木 崇 ${ }^{* 2}$ ，梶原 浩一 ${ }^{* 3}$ ，田川 泰敬 ${ }^{* 4}$
}

\section{Development of active seismic base isolation system with mechanical controller (Proposal of the concept, demonstration experiment and parameter study)}

\author{
Yasuo AOKI ${ }^{* 1}$, Akinori HIRAMATSU ${ }^{* 2}$, Tempei WACHI ${ }^{* 2}$, Takashi AOKI ${ }^{* 2}$, Kouichi KAJIWARA ${ }^{* 3}$ \\ and Yasutaka TAGAWA ${ }^{*}$ \\ ${ }^{* 1,}{ }^{* 2,}{ }^{* 4}$ Tokyo University of Agriculture and Technology Dept. of Mechanical Systems Engineering \\ 2-24-16 Naka-cho, Koganei-shi, Tokyo 184-8588, Japan \\ ${ }^{*}$ National Research Institute for Earth Science and Disaster Prevention \\ 3-1 Tennodai, Tsukuba-shi, Ibaraki 305-0006, Japan
}

\section{Received 5 September 2014}

\begin{abstract}
Many active seismic isolation systems and active seismic vibration control systems have now being produced to reduce earthquake damage as much as possible by suffering from recent frequent huge earthquakes. Existing active vibration isolation device systems are controlled by computers. They are driven by the commands given to actuator. Those commands are calculated as control inputs using movements of earthquake, building and actuator monitored with electric sensors. These systems have such advantage that the control characteristics can be changed easily by modifying the program algorithm. However, these electronic systems have some points of weakness. Computer itself and software should be updated to the latest model every several years. Small troubles like electrical disconnection, or electronic component parts aging deterioration or malfunction could cause total functional failure. In case the worst case takes place, it might go out of control. To solve this problem replacement of computer control instruction with highly reliable machinery mechanism using no electronic component is proposed in this study. The method of replacement of electronic control with machinery mechanism is as follows. Through link mechanism relative movement displacement between earthquake and building seismic vibration is transmitted to spool as command signal and direction of hydraulic pressure is changed to activate for seismic control
\end{abstract}

Key words : Active seismic isolator, Vibration control, Mechanical controller, Hydraulic spool

\section{1. 緒言}

東日本大震災をはじめ，世界各国で大地震が発生し，多くの被害をもたらしている．このような地震の発生時 に建物の倒壊を防ぐため，油圧アクチュエータを用いた免震あるいは制振制御を行う技術が提案され，実用化さ れている（吉田他，2010）（吉田他，2012）（小鹿，2011）。これらの装置は，センサによって検知した地震波から 電子装置でアクチュエータを制御することで，建物が摇れることを抑えている（渡辺他，2010）（斉藤，2008）. これらの技術は，演算装置内で制御則を自由に設定できるという利点があげられる。一方で，建物の寿命が 50 年以上であるのに対し，電気・電子機器およびこれらを制御するソフトウエアは数年単位でモデルチェンジある いはアップデートが行われているため，そのハードウエアおよびソフトウエアの更新やメンテナンスが大きな課 題となっている．また，制御を行うために必要となるセンサ類が検出限界を超えたときや欠陥を含むなどした場

\footnotetext{
No.14-00450 [DOI:10.1299/transjsme.14-00450], J-STAGE Advance Publication date : 28 January, 2015

*1 正員，東京農工大学 工学府（干184-8588 東京都小金井市中町 2-24-16）

"2 東京農工大学 工学府

*3 正員，(独) 防災科学技術研究所（テ305-0006 茨城県つくば市天王台 3-1）

*4 正員, フェロー 東京農工大学 工学府

E-mail of corresponding author: 50009833701@ st.tuat.ac.jp
} 
合，予期せぬ動作を起こす可能性がある．さらに，震災発生時に断線などにより装置自体が正常に機能しないこ とも想定される. 地震発生時に, 免震・制振装置の確実な動作の重要性が改めて認識されており（藤田, 鎌田, 1994a，1994b），より単純で簡単な機構で構成され，震災時に確実に動作する信頼性の高いアクティブ免震・制振 装置が求められている.

筆者らはこれらの技術を応用し，従来型の電子装置を用いるアクティブ免震システムに代わり，単純な機械的 な機構からなる油圧アクティブ免震システムを提案する. 本研究では, 地震動が入力される地面と建物, 油圧切 り替え弁間を機械的リンクおよびばねで接続し，電子制御なしに油圧の方向を切り替え，油圧アクチュエータを 駆動することにより, 確実で安定した免震, 制振制御を可能とするシステムの開発を目指す (和地他, 2012a, 2012b).

本論文では，まず 2 章で提案する機構のモデル化について述べ，3 章でそのモデルを用いたシミュレーション を実施，4 章の実駼結果によって，その有効性を示す．また， 5 章では本機構の実用化に向けて，機構の各パラメ 一タが免震性能へ与える影響について考察する.

\section{2. 提案する機構}

本研究で提案する機構の概念図を図 1 に示す. 本機構は, 地面と構造物の間に免震ゴムを設置する一般的な免 震構造物に加え，構造物に力を付加する油圧アクチュエータ，アクチュエータの制御を行うスプール弁，地面か ら構造物への相対変位をスプール弁に伝えるリンク機構によって構成される．スプール内部はアクチュエータの シリンダロッドによって 3 つに分けられ, 中央の部屋に高圧の油圧が供給されている. 図 1 の赤い破線で囲まれ たリンク，スプール部が電子制御に代わり油圧アクチュエータへの入力として作動油の方向切換, 流量制御をし ている．また，地面とシリンダロッドをつないでいるばねとダッシュポットは，アクチュエータの変位量に対し て構造物に加わる力を最適にする役割がある.

地面が加振され移動すると（図 1(b)中の 1), リンクによって固定されていたスプールに地面と構造物の相対変位 が伝わり，シリンダロッドに先行して変位が与えられる（図 1(b)中の 2)。その結果，スプールの弁が開き，油圧 源からアクチュエーターの流路が開くことで (図 1(b)中の 3), 加振とは逆向きの力が構造物にかかる. またこの ときスプールの開量によって流量が調整されるため，スプールに大きな変位がかかるほど，アクチュエータから より大きな力が構造物に加えられる。 また, シリンダロッドの左端にばねとダンパ（図 2 の $k_{2}$ およ゙゙ $c_{2}$ ）を取 付けることにより，シリンダ内の急激な圧力変動やシリンダロッドの過渡な加速を抑制している.

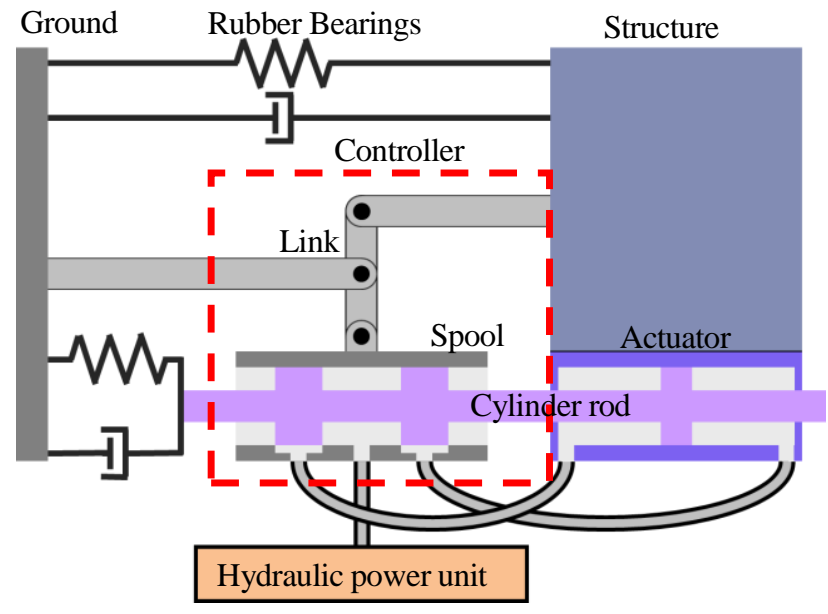

(a)

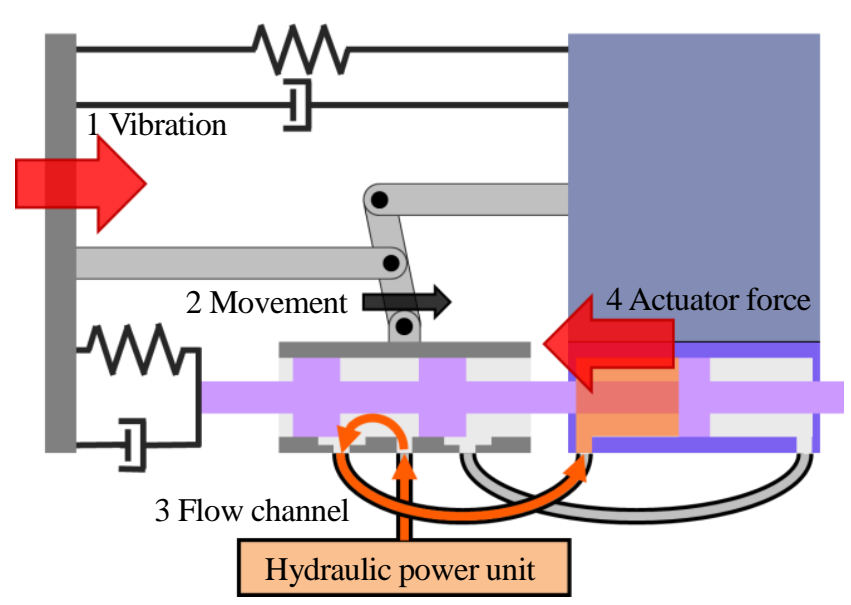

(b)

Fig. 1 Schema of a proposed mechanism. The links and spool enclosed with red line control the actuator. 


\section{3. 提案機構の機能性確認}

\section{$3 \cdot 1$ 装置のモデル化}

提案した機構の各要素のパラメータを図 2 に示す.

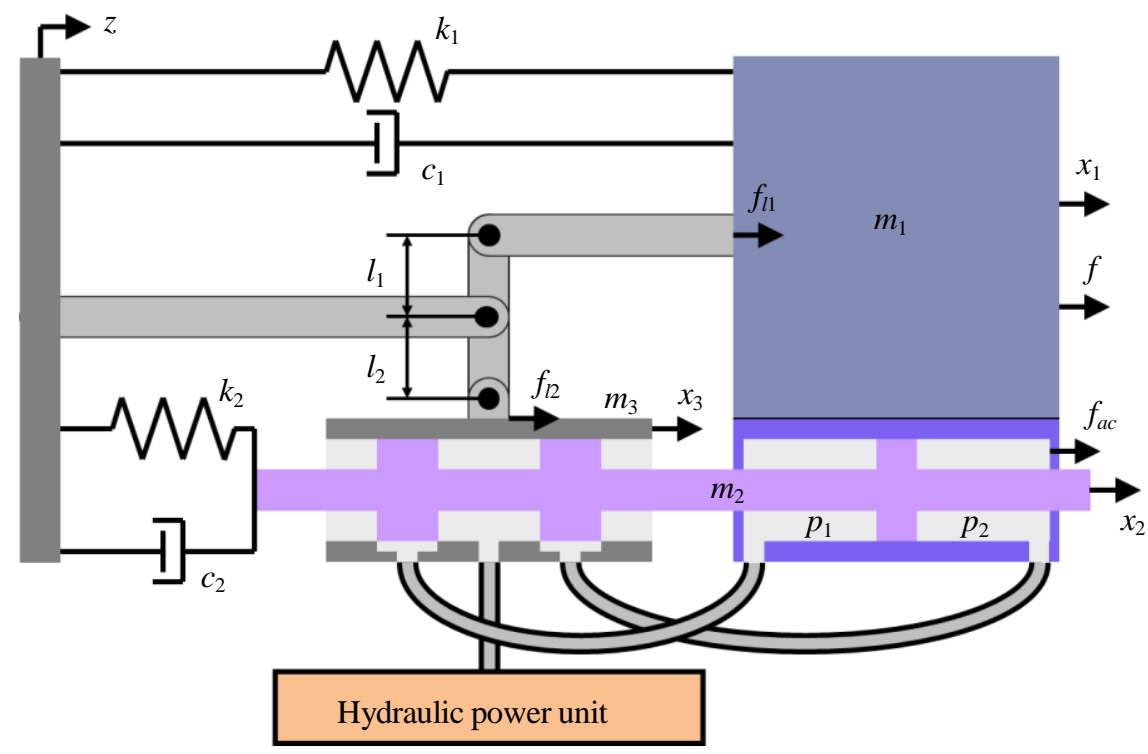

Fig. 2 Parameters of the model. In this paper, $z[\mathrm{~m}]$ is displacement of ground, $f[\mathrm{~N}]$ is external force to the structure model, $x_{1}$ $[\mathrm{m}], x_{2}[\mathrm{~m}]$ and $x_{3}[\mathrm{~m}]$ are relative displacements of structure, cylinder rod, and spool against the ground motion, $m_{1}$ $[\mathrm{kg}], m_{2}[\mathrm{~kg}]$ and $m_{3}[\mathrm{~kg}]$ are masses of the structure, cylinder rod, and spool, respectively. $l_{1}[\mathrm{~m}]$ and $l_{2}[\mathrm{~m}]$ are lengths of corresponded links. $k_{1}[\mathrm{~N} / \mathrm{m}]$ and $c_{1}[\mathrm{Ns} / \mathrm{m}]$ are spring coefficient and damping coefficient of the passive base isolation device. $k_{2}[\mathrm{~N} / \mathrm{m}]$ and $c_{2}[\mathrm{Ns} / \mathrm{m}]$ are spring coefficient and damping coefficient. $f_{l 1}[\mathrm{~N}]$ is force from link to the structure, $f_{12}[\mathrm{~N}]$ is force from link to the spool, $p_{1}[\mathrm{~Pa}]$ is left hand side pressure, and $p_{2}[\mathrm{~Pa}]$ is right hand side pressure in cylinder.

構造物，シリンダの受圧面積，スプール特性について運動方程式を立てたものを式（1）〜（3）に示す。この とき，リンクの質量，慣性モーメントは他の要素と比較して小さいため無視している.

パラメータの意味は下記のものである.

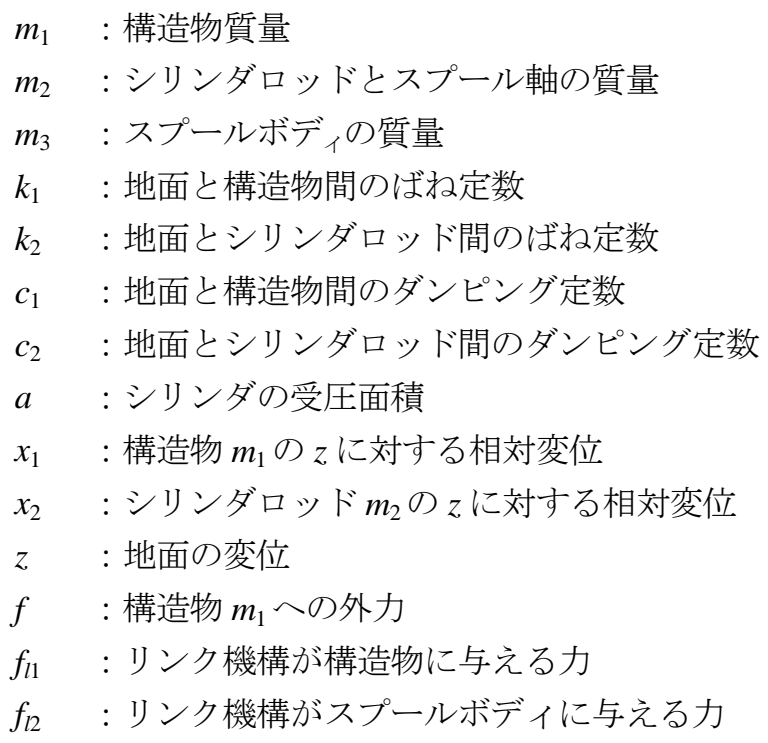




$$
\begin{aligned}
& m_{1}\left(\ddot{x}_{1}+\ddot{z}\right)=-k_{1} x_{1}-c_{1} \dot{x}_{1}+f+f_{l 1}+a p \\
& m_{2}\left(\ddot{x}_{2}+\ddot{z}\right)=-k_{2} x_{2}-c_{2} \dot{x}_{2}-a p \\
& m_{3}\left(\ddot{x}_{3}+\ddot{z}\right)=f_{l 2}
\end{aligned}
$$

ここで, $p$ は油圧アクチュエータ内の左右の部屋の圧力差 $p=p_{2}-p_{1}[\mathrm{~Pa}]$ を示寸. また, リンクの慣性モーメン トは 0 としているため, $h=l_{2} / l_{1}$ とすると, 以下の式 (4) を得る.

$$
f_{l 1}=h f_{l 2}
$$

式(4)の関係を用いて，式（1）に式（3）を代入すると，以下の式（5）を得る.

$$
m_{1}\left(\ddot{x}_{1}+\ddot{z}\right)=-k_{1} x_{1}-c_{1} \dot{x}_{1}+f+h m_{3}\left(\ddot{x}_{3}+\ddot{z}\right)+a p
$$

また，リンクによる拘束の関係から，式（5）に $x_{3}=-h x_{1}$ を代入すると以下の式（6）を得る.

$$
\ddot{x}_{1}\left(m_{1}+h^{2} m_{3}\right)+\ddot{z}\left(m_{1}-h m_{3}\right)=-k_{1} x_{1}-c_{1} \dot{x}_{1}+f+a p
$$

スプール弁から流出する油の体積流量は弁の開量に比例し, その比例定数を $q\left[\mathrm{~m}^{2} / \mathrm{s}\right]$ とすると, スプール弁から 入出する油，油圧アクチュエータに流入する油には以下の式（7）の関係が成り立つ.

$$
q\left(h x_{1}+x_{2}\right)=a\left(\dot{x}_{1}-\dot{x}_{2}\right)
$$

ここで, 油の体積弹性率を $b\left[\mathrm{~Pa}^{-1}\right]$, 油圧シリンダ体積を $V\left[\mathrm{~m}^{3}\right]$ とおき, 油圧アクチュエータ内の圧力が変化す ることにより油が圧縮された事を考慮すると, 以下の式（8）を得る.

$$
q\left(h x_{1}+x_{2}\right)-\frac{b V}{2} \dot{p}=a\left(\dot{x}_{1}-\dot{x}_{2}\right)
$$

さらに, 油の流入先の圧力が高い場合, 流入量が減少する. スプールの差圧力による流量低下係数を $r\left[\mathrm{~m}^{3} / \mathrm{Pa}\right.$. s]とすると式（8）は以下のようになる.

$$
q\left(h x_{1}+x_{2}\right)-\frac{b V}{2} \dot{p}=a\left(\dot{x}_{1}-\dot{x}_{2}\right)+r p
$$

式 (2)，（6），(9）から $x_{1} ， \dot{x}_{1}, x_{2}, \dot{x}_{2}, p$ を状態量， $\ddot{z} ， f$ を入力として提案するシステム全体の状態方程式を立 てたものを式（10）に示す. 
Aoki, Hiramatsu, Wachi, Aoki, Kajiwara and Tagawa,

Transactions of the JSME (in Japanese), Vol.81, No.823 (2015)

$$
\begin{aligned}
\left\{\begin{array}{l}
\dot{x}_{1} \\
\ddot{x}_{1} \\
\dot{x}_{2} \\
\ddot{x}_{2} \\
\dot{p}
\end{array}\right\} & =\left[\begin{array}{ccccc}
0 & 1 & 0 & 0 & 0 \\
-\frac{k_{1}}{m_{1}+h^{2} m_{3}} & -\frac{c_{1}}{m_{1}+h^{2} m_{3}} & 0 & 0 & \frac{a}{m_{1}+h^{2} m_{3}} \\
0 & 0 & 0 & 1 & 0 \\
0 & 0 & -\frac{k_{2}}{m_{2}} & -\frac{c_{2}}{m_{2}} & -\frac{a}{m_{2}} \\
\frac{2 h q}{b V} & -\frac{2 a}{b V} & \frac{2 q}{b V} & \frac{2 a}{b V} & -\frac{2 r}{b V}
\end{array}\right]\left\{\begin{array}{l}
x_{1} \\
\dot{x}_{1} \\
x_{2} \\
\dot{x}_{2} \\
p
\end{array}\right\} \\
& +\left[\begin{array}{cc}
0 \\
-\frac{m_{1}-h m_{3}}{m_{1}+h^{2} m_{3}} & \frac{1}{m_{1}+h^{2} m_{3}} \\
0 & 0 \\
-1 & 0 \\
0 & 0
\end{array}\right]\left\{\begin{array}{l}
\ddot{z} \\
f
\end{array}\right\}
\end{aligned}
$$

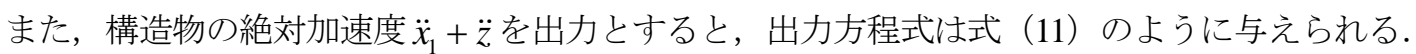

$$
\begin{aligned}
& \ddot{x}_{1}+\ddot{z}=\left[\begin{array}{lllll}
-\frac{k_{1}}{m_{1}+h^{2} m_{3}} & -\frac{c_{1}}{m_{1}+h^{2} m_{3}} & 0 & 0 & \frac{a}{m_{1}+h^{2} m_{3}}
\end{array}\right]\left\{\begin{array}{c}
x_{1} \\
\dot{x}_{1} \\
x_{2} \\
\dot{x}_{2} \\
p
\end{array}\right\} \\
& +\left[\begin{array}{cc}
-\frac{m_{1}-h m_{3}}{m_{1}+h^{2} m_{3}}+1 & \frac{1}{m_{1}+h^{2} m_{3}}
\end{array}\right]\left\{\begin{array}{l}
\ddot{z} \\
f
\end{array}\right\}
\end{aligned}
$$

\section{$3 \cdot 2$ シミュレーション結果}

式（10)，（11）で示したモデルを用いて，構造物の絶対加速度を出力として，地面加速度から構造物加速度ま での伝達特性（周波数応答特性）のシミュレーションを行った. また，比較対象として制御機構部を取り外し， 剛性，減衰のみで接続されたパッシブ免震構造を想定した場合のモデルを導き，同様のシミュレーションを行っ た．以下にシミュレーションで用いた值を示す．これらの值は実験装置を参考に決定した.

$$
\begin{array}{llll}
m_{1} & : 260 \mathrm{~kg} & h & : 2 \\
m_{2} & : 3 \mathrm{~kg} & a & : 4.1 \times 10^{-4} \mathrm{~m}^{2} \\
m_{3} & : 7 \mathrm{~kg} & b & : 7.14 \times 10^{-10} 1 / \mathrm{Pa} \\
k_{1} & : 41058 \mathrm{~N} / \mathrm{m} & V & : 3.1 \times 10^{-5} \mathrm{~m}^{3} \\
k_{2} & : 30170 \mathrm{~N} / \mathrm{m} & q & : 1.288 \times 10^{-2} \mathrm{~m}^{2} / \mathrm{s} \\
c_{1} & : 598 \mathrm{Ns} / \mathrm{m} & r & : 1.083 \times 10^{-9} \mathrm{~m}^{3} /(\mathrm{Pa} \cdot \mathrm{s}) \\
c_{2} & : 1000 \mathrm{Ns} / \mathrm{m} & &
\end{array}
$$

パッシブ免震を想定したモデルの剛性と減衰は, 図 2 で示した機構の地面, 構造物間の岡性 $k_{1}$ と減衰 $c_{1}$ を使用 し，構造物質量も同様に $m_{1}$ を使用した．図 3 に周波数応答特性の比較を行ったシミュレーション結果を示す. 図 3 から，提案する機構によりパッシブ免震に対して共振ピークの抑制が可能であることを確認した。 この結果か ら既にあるパッシブ免震の建築物にこの機構を用いることで更にピークを下げることが期待できる. 

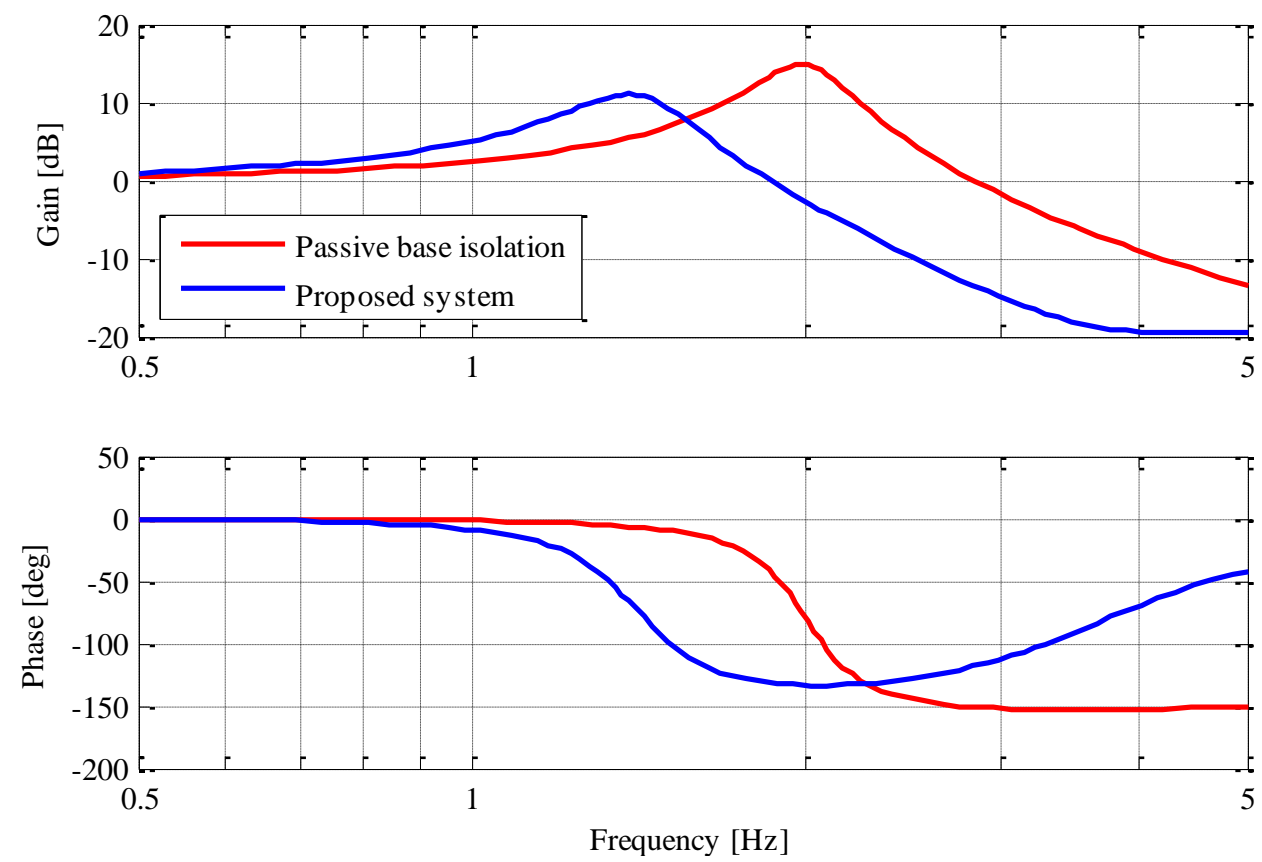

Fig. 3 Simulation results. This graph shows frequency response of acceleration from the ground to the structure. The red line indicates the passive base isolation and the blue line indicates the proposed system.

\section{$3 \cdot 3$ 実験装置}

提案する機構の実験装置によって，実際に機構が機能することを確認する. 図 4 に製作した実験装置を示す. 青の破線部が構造物モデル，黄の破線が地面に相当する台車，赤い破線が制御機構であるスプール弁とリンク機 構となる．構造物モデルには油圧アクチュエータが取り付けてあり，そのロッドはスプールの軸と直接つながっ ている，各要素はレール上に配され，油圧加振装置によって地面に相当する台車を変位制御で変位振幅を一定に 保ちながら周波数掃引して加振する. 制御機構部のスプールには，油圧源であるオイルポンプから，一定圧力の 油が供給されている．当初，リンク機構の回転部，スプールの摺動摩擦の影響で動作に再現性がなくなり，十分 な免震効果が得られなかった。この問題を解決するために，リンクのヒンジ部に小型ラジアルボールベアリング を組入れ，スプールの両側軸受部には，軸芯を合わせてドライブッシュを組込み，スプール軸とケース間の芯を 厳密に合わせた．スプールにはパッキンの摩擦を避けるためにパッキンは全く使用していない. スプールの油圧 回路方向切り替え性能は，スプール幅を少しオーバーラップするように作り，油圧回路の切り替え性能の向上を 図った。また，台車，構造物モデル，シリンダロッド，スプールケースの変位，加速度を計測した。

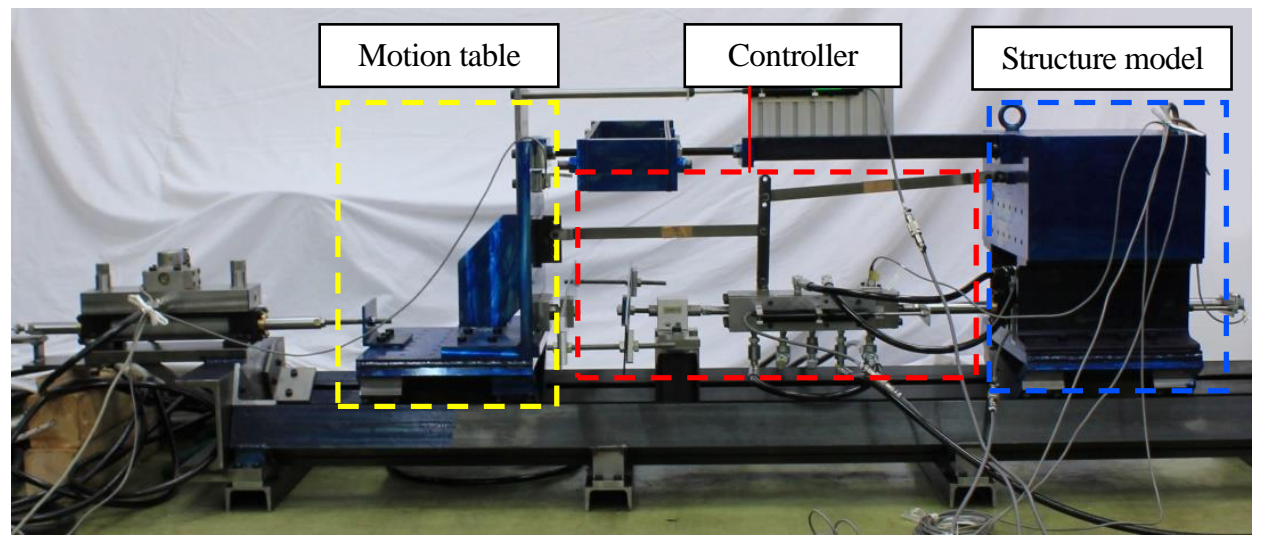

Fig. 4 Experimental apparatus. A part enclosed with blue line is the structure model, a part enclosed with yellow line is the motion table, and a part enclosed with red line is the controller composed by the spool and links. The structure model has an oil hydraulic cylinder as an actuator, whose cylinder rod is connected to the spool. 
Aoki, Hiramatsu, Wachi, Aoki, Kajiwara and Tagawa,

Transactions of the JSME (in Japanese), Vol.81, No.823 (2015)

\section{4. 実験結果}

\section{$4 \cdot 1$ ステップ応答実験}

はじめに，図 4 で示した実験装置に地面変位として $9 \mathrm{~mm}$ のステップ変位を与える実験を行った，制御機構部 をつけた場合と外した場合において，構造物モデルの加速度を比較した結果を図 5 に示す. 実験結果より本機構 により構造物に大きな減衰が与えられていることがわかる.

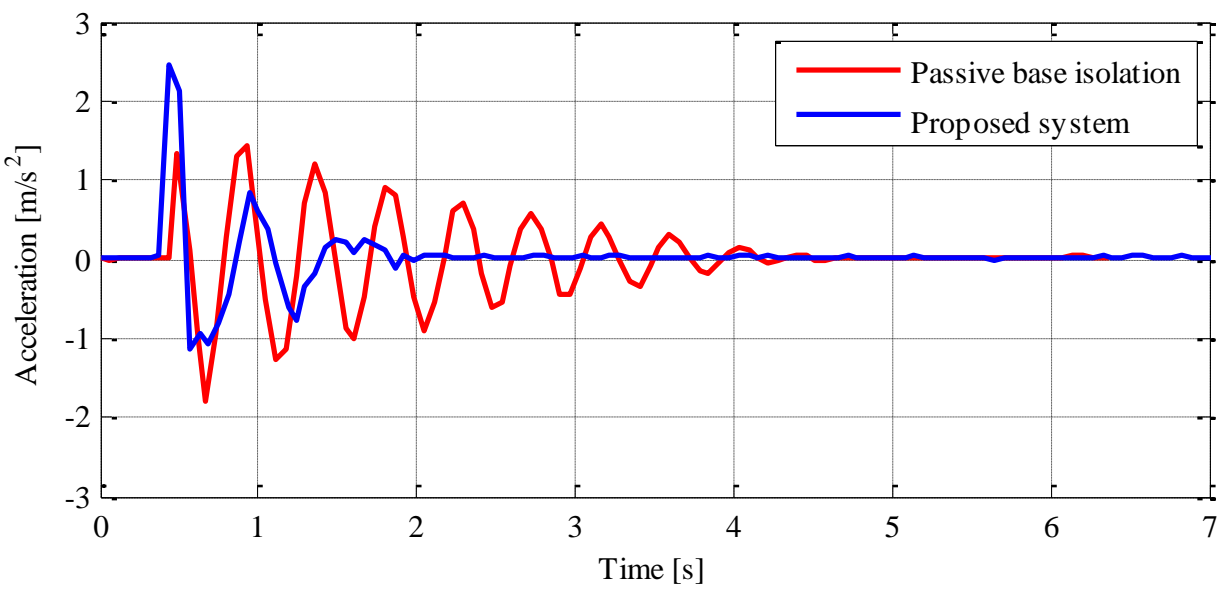

Fig. 5 Step responses in experiments. Red line shows acceleration of the structure model when step displacement is added to passive base isolation, and the blue line shows that when step displacement is added to the proposed system.

\section{$4 \cdot 1$ 周波数掃引実験}

次に，振幅 $4.5 \mathrm{~mm}$ で一定，0〜 $60 \mathrm{sec}$ で $0.5 \mathrm{~Hz}$ から $5 \mathrm{~Hz}$ に変化するスイープサイン波を入力する加振実験を 行った。また，比較対象として，制御機構部を取り外し，パッシブ免震系とした場合の装置でも同様の実験条件 での加振実験を行った，変位センサによってテーブル，構造物モデルの絶対変位を求め，周波数応答特性は，テ 一ブル変位を入力，構造物モデルの絶対変位を出力として求めた．実験の結果得られた各時刻歴応答を図 6 に示 す.図 6 より，制御がある場合は，制御のない場合と比べ振幅のピークが小さくなっていることが分かる.また， ピークを超えた高い周波数においても振幅が小さくなっている.

図 6 の結果を周波数応答特性にしたものを図 7 に示す. 図 7 より，図 3 のシミュレーションと同等の実験結果が 得られていることから，提案する機構が実際の装置で再現できることが確認された

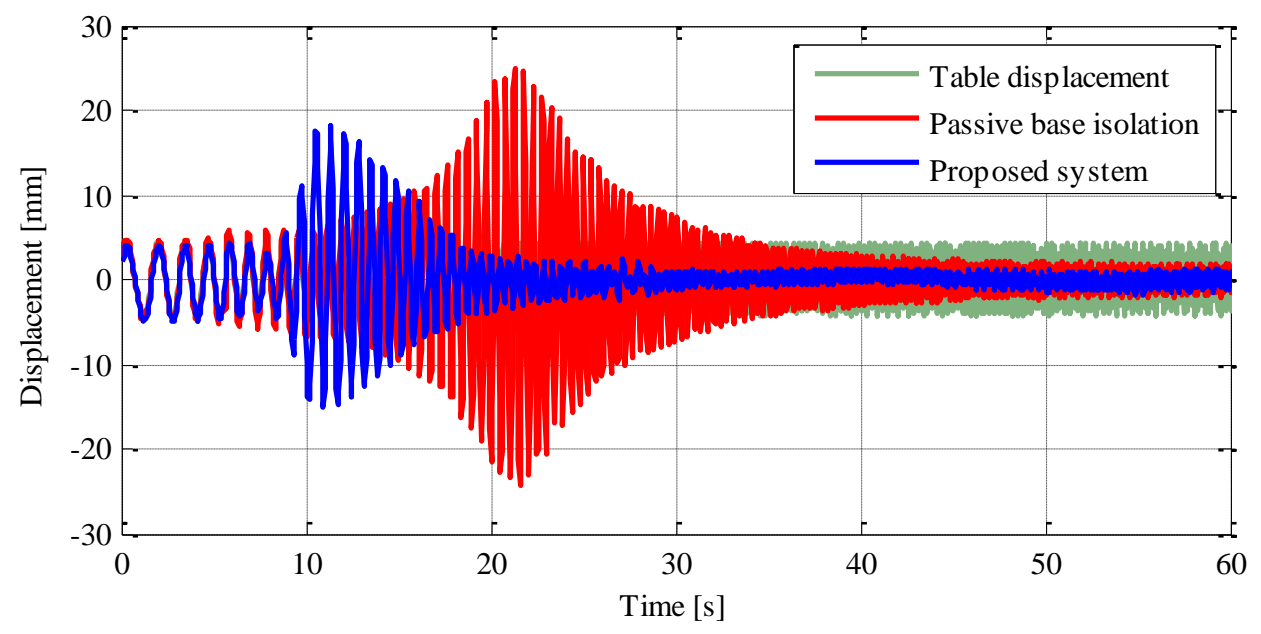

Fig. 6 Time response in experiments. Green line shows sweep sine wave of the ground. Red line shows absolute displacement of the structure model when the sweep sine wave is input to the passive base isolation system, and blue line shows absolute displacement when sweep sine wave is input to the proposed system. 

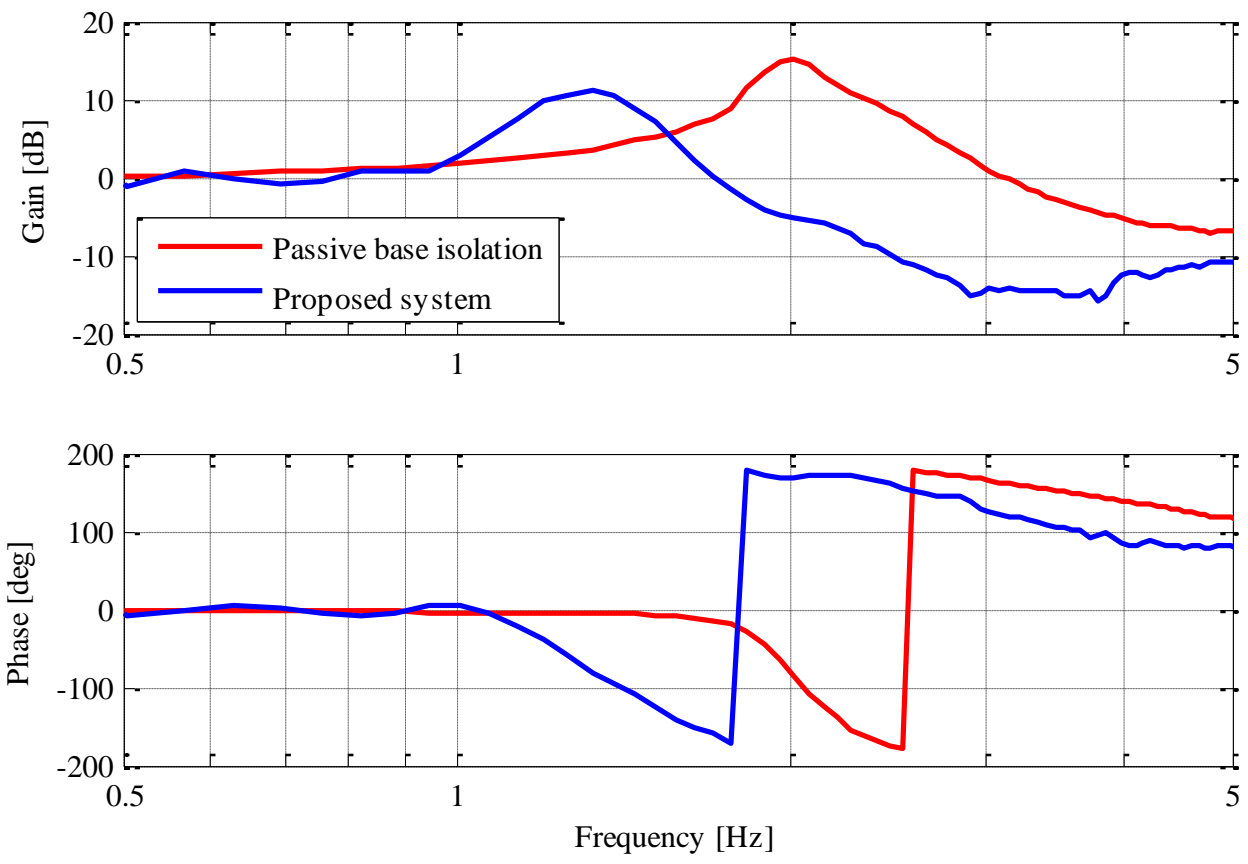

Fig. 7 Frequency response with/without control in experiments. This graph shows frequency response of absolute displacement from the ground to the structure. Red line shows the passive base isolation case, and blue line shows the proposed system case.

\section{5. 各種パラメータの免震性能への影響}

\section{$5 \cdot 1$ リンクの長さ比の影響}

本節では, 装置のパラメータを変化させ, モデルの特性への影響を調べる. 実際の装置での変更が容易であり, 任意のパラメータを再現しやすいものとして, リンク機構部の腕の長さの比 $h=l_{2} / l_{1}$ に注目した. $h$ は構造物モデ ルの位置をスプールに伝える際の，それぞれの変位量の比率を決定している.

リンクの長さ比 $h$ が大きくなると, 構造物モデルの変位に対するスプールの変位量が大きくなるため, 機構の 応答性がよくなると考えられる. リンクの長さ比 $h$ を変化させた際の伝達特性の変化を比較したシミュレーショ ン結果を図 8 に示寸.

図 8 から，リンク比を大きく寸ることで，減衰比が大きくなり，固有振動数が小さくなることが分かる. 高周 波帯になるとゲインの減少がとまり若干の上昇が見られるが，これについては $5 \cdot 2$ にて詳述する.

リンクの長さ比 $h$ を $0.5 ， 1.0 ， 1.5 ， 2.0$ と変更して，4・2 と同様の条件で実験を行った. リンクの長さ比 $h$ を 変えた場合と制御のない場合について, 実験結果の周波数応答特性を図 9 に示寸. 図 8 , 図 9 より, リンクの長 さ比 $h$ をきくしていくことで, シミュレーションと同様に減衰比が大きくなり，固有振動数が小さくなってい ることが確認できた．このことから，リンクの長さ比 $h$ 変更することで，ピークを下げられるだけでなく，特 定の周波数からの共振を避けることが可能であると考えられる 

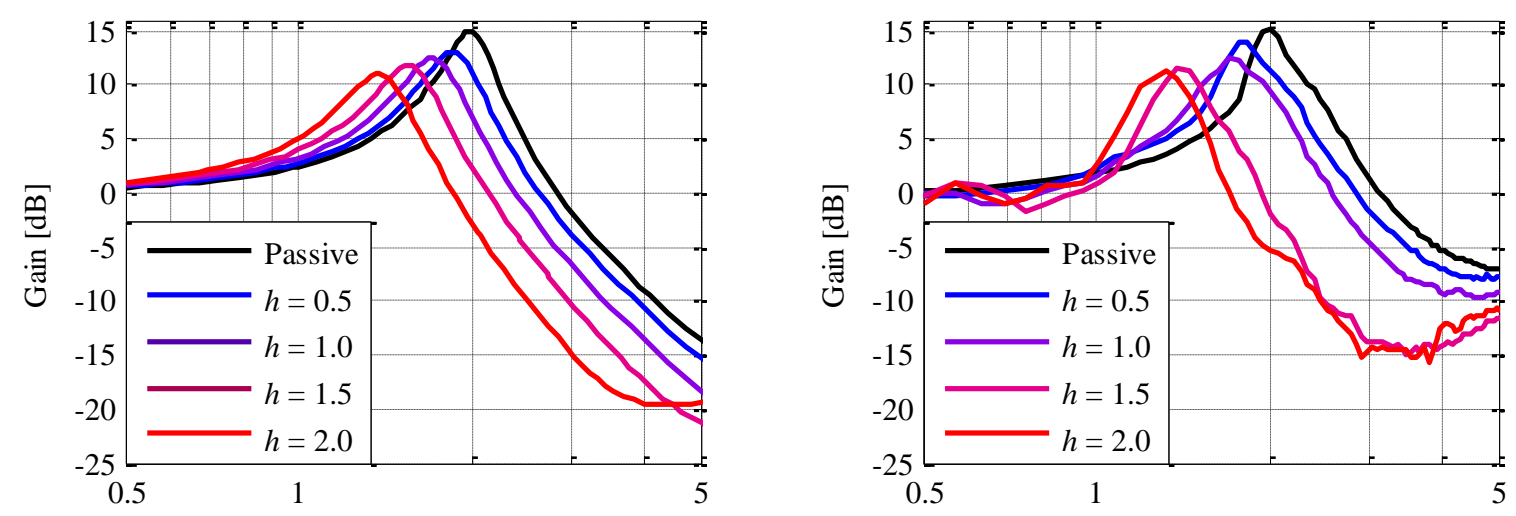

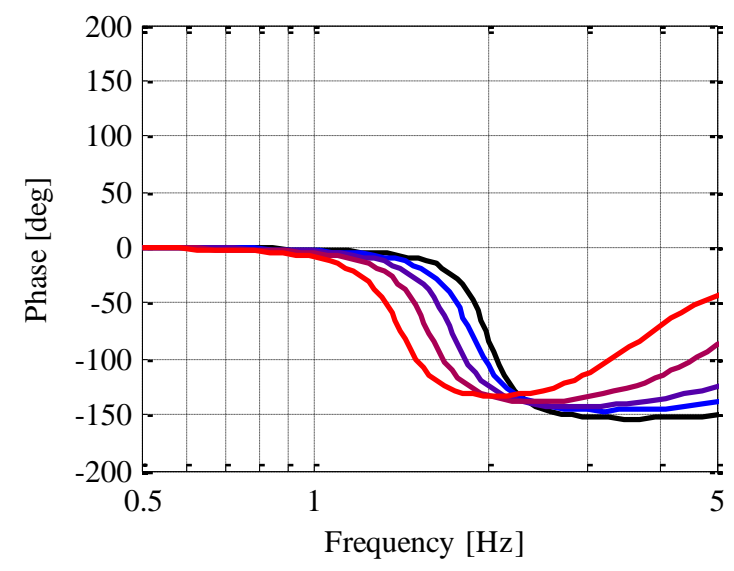

Fig. 8 Frequency response(Simulation).

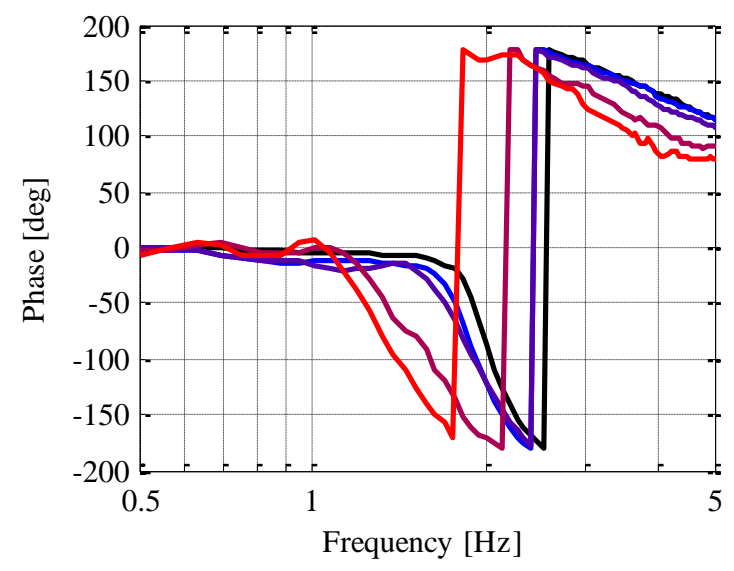

Fig. 9 Frequency response(Experiment).

Black line shows the frequency response of the passive base isolation system, and the other lines whose color change from blue to red show those of the proposed system with link ratio $h=0.5,1.0,1.5,2.0$. Fig.8 and Fig. 9 show simulation and experimental results respectively.

\section{$5 \cdot 2$ スプールおよびアクチュエータの影響}

この系において，4 Hz 以上の高周波帯でのゲインの上昇には，スプール部の質量 $m_{3}$ が大きく関与している. 式（11）に示寸出力方程式の $\{\ddot{z} \quad f\}^{T}$ にかかる係数行列（以下 $\boldsymbol{D}$ 行列と呼ぶ）に注目する. $\boldsymbol{D}$ 行列の中で， 1

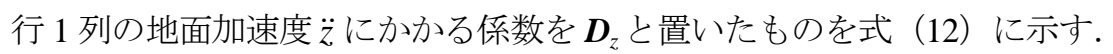

$$
D_{z}=-\frac{m_{1}-h m_{3}}{m_{1}+h^{2} m_{3}}+1
$$

一般に $\boldsymbol{A}, \boldsymbol{B}, \boldsymbol{C}, \boldsymbol{D}$ 行列で構成される状態方程式において, $\boldsymbol{D}$ 行列は，入力が直接出力に現れる影響を示す行列 (直達行列) であり, $\boldsymbol{D}$ の要素が非ゼロの場合, 対応する入出力間の伝達関数の分母と分子の次数が等しくなり, 高周波における最終的なゲインの傾きが一定 $(0 \mathrm{~dB} / \mathrm{dec})$ となる. 一方, $\boldsymbol{D}$ の要素が 0 の場合, 対応する入出力 間の伝達関数の分子の次数が分母の次数より小さくなり（厳密にプロパー，周波数が高くなるほどゲインが小さ くなることが知られている. 式(12)より, $m_{3} \neq 0$ のとき $D_{z} \neq 0$ となり, 上述の性質から, 地面入力加速度 $\ddot{z}$ から 構造物の絶対加速度 $\ddot{x}_{1}+\ddot{z}$ までの振動伝達率は高周波で一定となりそれ以上の免震効果は期待できない.しかし, 
Aoki, Hiramatsu, Wachi, Aoki, Kajiwara and Tagawa,

Transactions of the JSME (in Japanese), Vol.81, No.823 (2015)

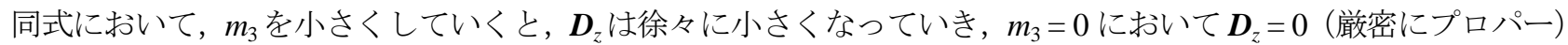
となる.このことから， $m_{3}$ を小さくとることにより高周波数領域でも良好な免震性能が得られることが期待でき る. 図 10 に，スプール質量 $m_{3}$ を変化させたときの地面入力加速度 $\ddot{z}$ から構造物の絶対加速度 $\ddot{x}_{1}+\ddot{z}$ までの周 波数応答特性のシミュレーション結果を示寸．上述の予測通り， $m_{3}$ が小さい程， $m_{3}=0$ の黒の破線に近づき，高 い周波数領域で良好な免震性能が得られていることがわかる. 本研究で用いた実験装置は, 設置場所やコストの 制約から，構造物に相当する質量 $m_{1}$ を十分大きくとることができなかったため，相対的にスプール質量 $m_{3}$ が大 きくなり，高周波での免震性能の低下を招いている．しかし，実構造物への適用を考えた場合， $m_{1}$ は $m_{3}$ に対し て十分大きいため，このような高周波での免震性能の低下を回避することができる.
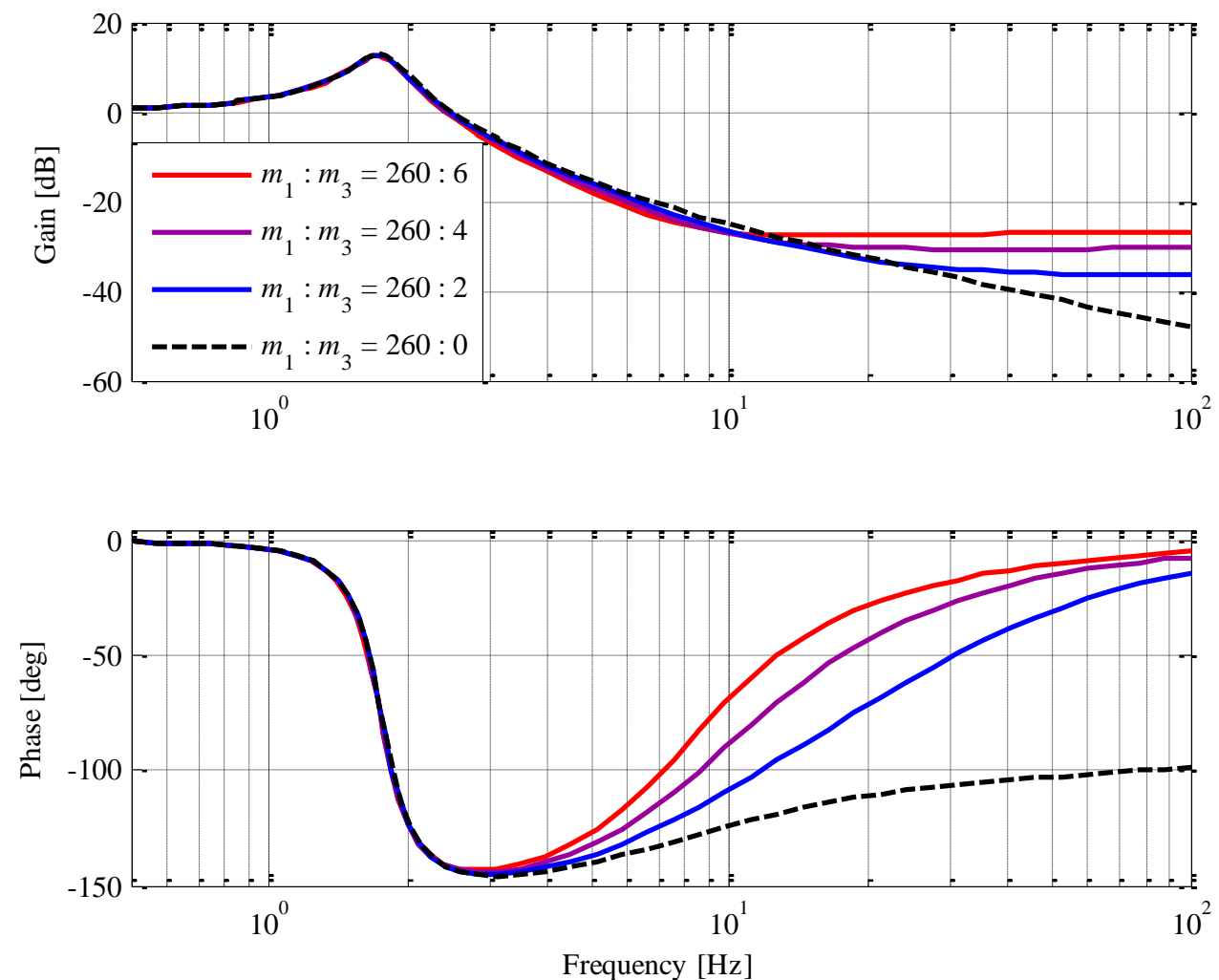

Fig. 10 Effectiveness of the mass $m_{3}$. Lines whose color change from red to blue show the frequency response of the proposed system with mass of spool $m_{3}=6 \mathrm{~kg}, 4 \mathrm{~kg}, 2 \mathrm{~kg}$, and black line shows frequency response in case of $m_{3}=0$.

次にアクチュエータの出力に関わる, 受圧面積 $a$, スプールの開量に対する油の流量の比例定数 $q$ に注目した. まず，受圧面積 $a$ を変化させたときのシミュレーション結果を図 11 に示す．図 11 より，受圧面積 $a$ を調整する ことで滅衰比を大きくすることができることが確認された.

また, 図 12 に比例定数 $q$ を変化させたときのシミュレーション結果を示寸. 図 12 より, 比例定数 $q$ も受圧面 積 $a$ 同様，調整することで減衰比を大きくすることができることが分かる. 

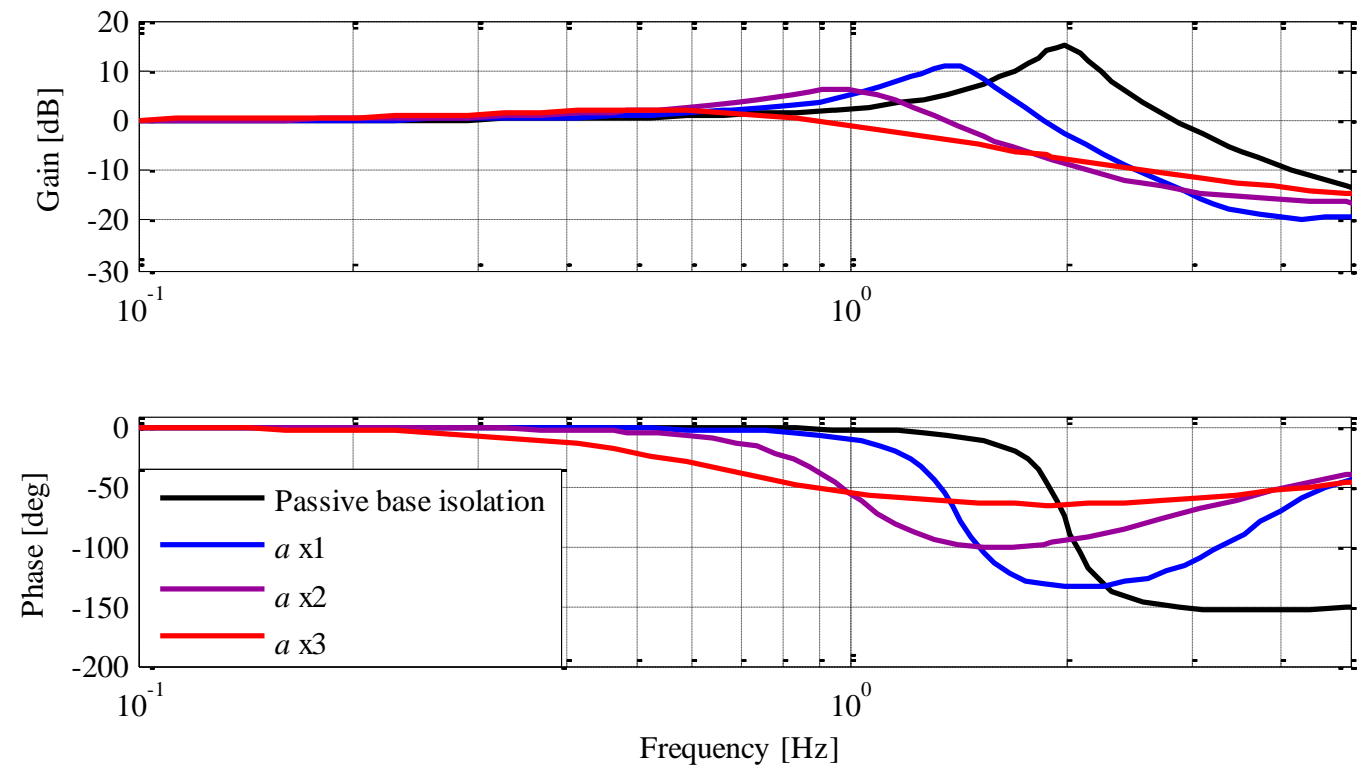

Fig. 11 Effectiveness of parameter $a$. Black line shows frequency response of the passive base isolation system, and the lines whose color change from blue to red show those of the proposed system with area of cross section of actuator $a$ increased by one, two, and three times.
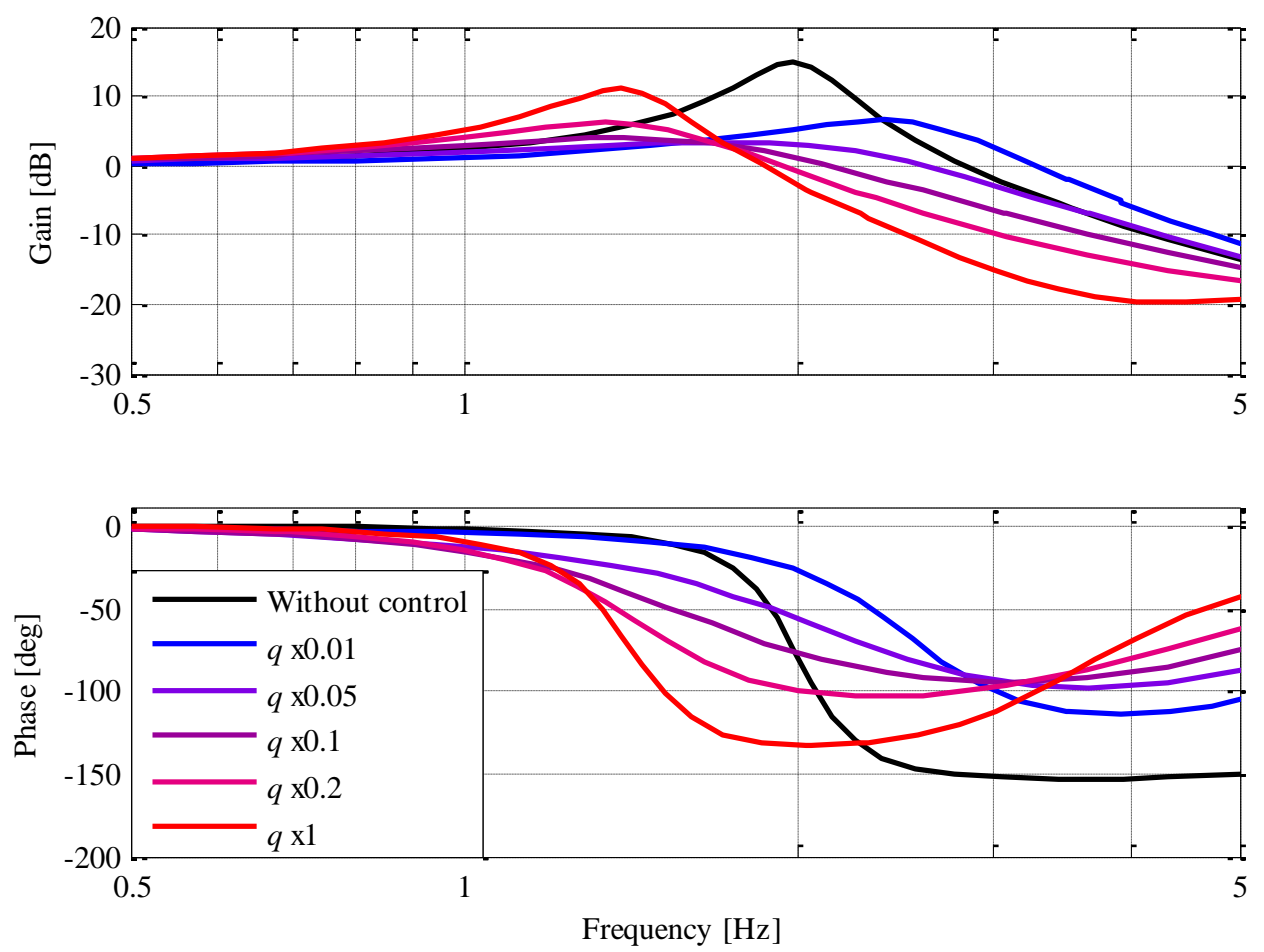

Fig. 12 Effectiveness of parameter $q$. Black line shows frequency response of the passive base isolation system, and lines whose color change from blue to red are those of the proposed system with coefficient $q$ decreased by $1,0.2,0.1,0.05$, and 0.01 times. 
Aoki, Hiramatsu, Wachi, Aoki, Kajiwara and Tagawa,

Transactions of the JSME (in Japanese), Vol.81, No.823 (2015)

シリンダ受圧面積 $a$ とスプールの開量に対する油の流量の比例定数 $q$ による影響の関係を調べるために, $a$ と $q$ の双方を変化させたときの共振ピークの変化をプロットしたものを図 13 に示す. 図 13 より, シリンダ受圧面積 $a$ ，比例定数 $q$ を調整することで，ゲインを最小にできることを確認した. 図 12 の曲線を用いることで，本機構 のスプール，アクチュエータの選定が容易になる， $a_{0}, q_{0}$ は，図 3 で用いた実験装置のパラメータを示す.

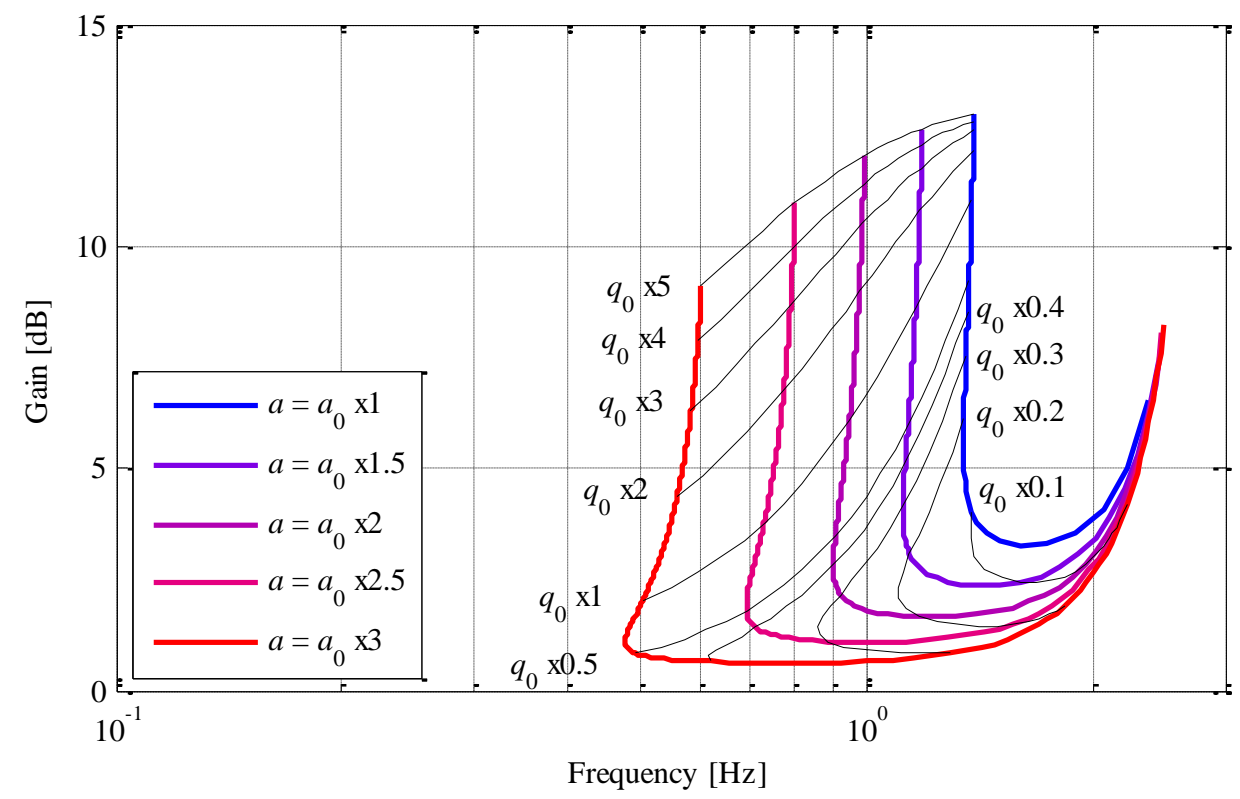

Fig. 13 Effectiveness of $a$ and $q$. Lines whose color change from blue to red show resonance peak position by changing parameters $q$ and $a$ of the proposed system. In this figure, $a_{0}=4.1 \times 10^{-4}\left[\mathrm{~m}^{2}\right], q_{0}=1.288 \times 10^{-2}\left[\mathrm{~m}^{2} / \mathrm{s}\right]$.

ゲインのピークを下げるだけであればパッシブ免震においてダンパの減衰定数を大きくするだけで可能である ため，本機構とパッシブ免震においてゲインピークを合わせた場合について比較する．図 14 は，図 13 に基づき パラメータを調整 $\left(a=a_{0} \times 3, q=q_{0} / 3\right)$ し，スプール質量 $m_{3}$ を 0 としたときのボード線図（青の破線）を，パッ シブ免震のみでダンパの減衰定数を大きくした場合（赤線）と比較したものである. 図 14 より，提案する機構 はパッシブ免震において減衰定数を大きくした場合より，共振ピークが下がることによる高周波のゲイン増加が 小さいことが確認された.
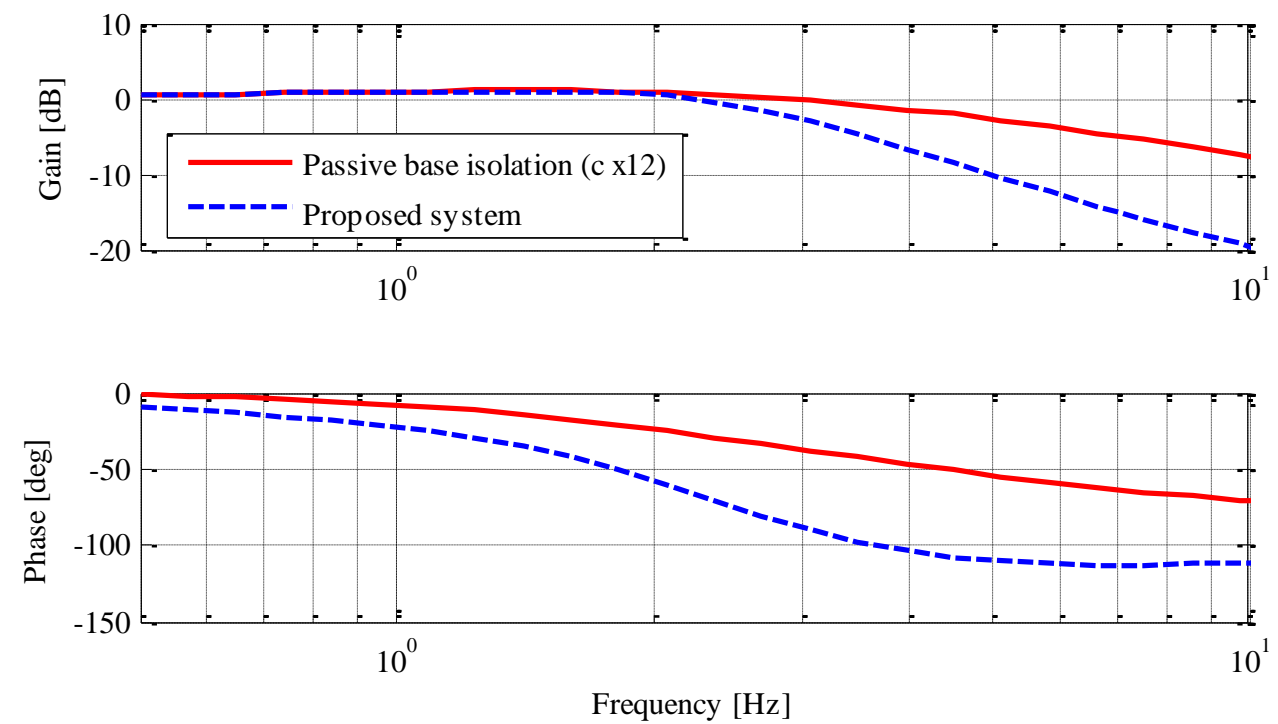

Fig. 14 Comparison between the passive system and the proposed system. Compared to the passive system (red line), the proposed system (blue dotted line) has better isolation performance especially in high frequency range. 
Aoki, Hiramatsu, Wachi, Aoki, Kajiwara and Tagawa,

Transactions of the JSME (in Japanese), Vol.81, No.823 (2015)

\section{$5 \cdot 3$ 外乱特性への影響}

風などにより建物に直接外乱が加えられた場合の特性について考える. 図 15 は，構造物にインパル状の外乱が 加えられた時の構造物の応答を，提案するシステムと従来の免震システムとで，比較したものである（本シミュ レーションでは，実験装置のパラメータを用いている)。図より提案するシステムとパッシブ免震システムでは, 外乱に対する減衰特性に，大きな変化が見られないことがわかる．これに対し，図 16 は，図 13 を用い， $a$ およ び $q$ の值を減衰が大きくなるように調整したときの，インパルス外乱に対する応答を示す．パラメータを調整す ることにより，構造物への直接外乱に対する制振性能が飛躍的に向上していることがわかる.

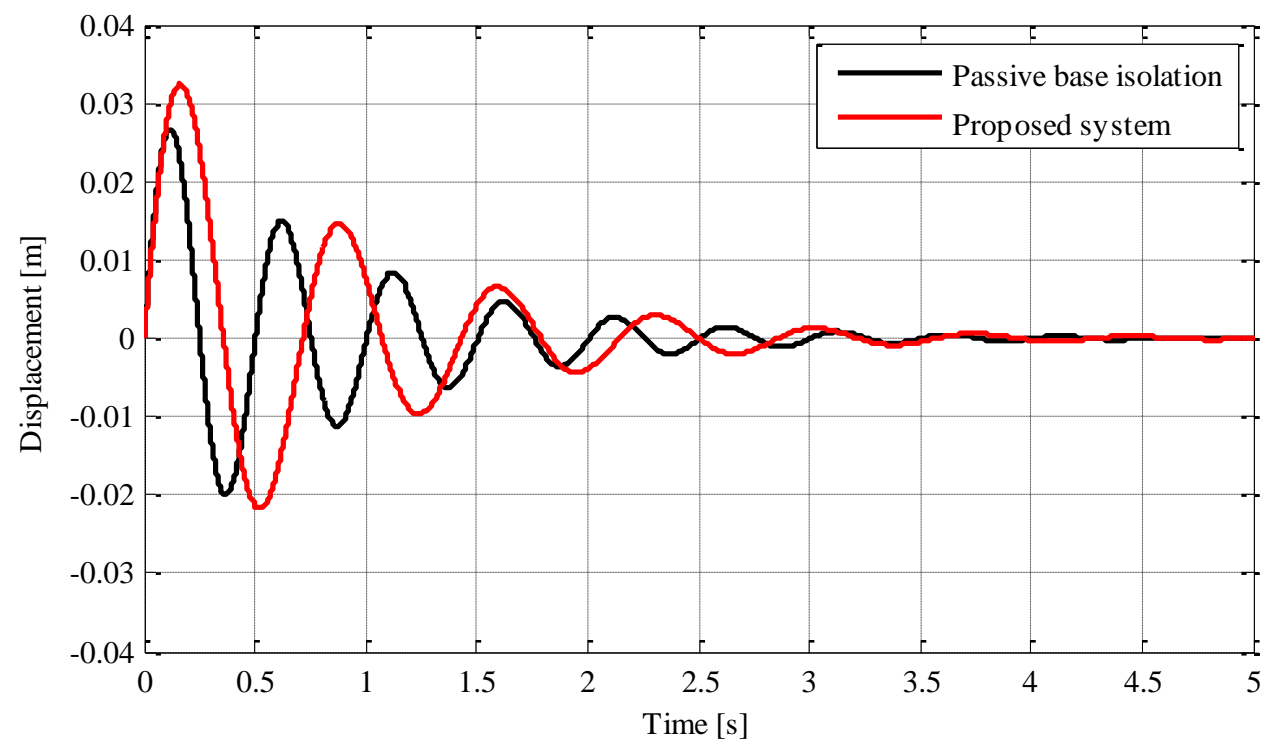

Fig. 15 Time responses of the structure for impulse disturbance. Black line shows absolute displacement of the structure model when impulse external force to the structure model is input for the passive base isolation system, and red line shows the absolute displacement when the same impulse external force is input for the proposed system.

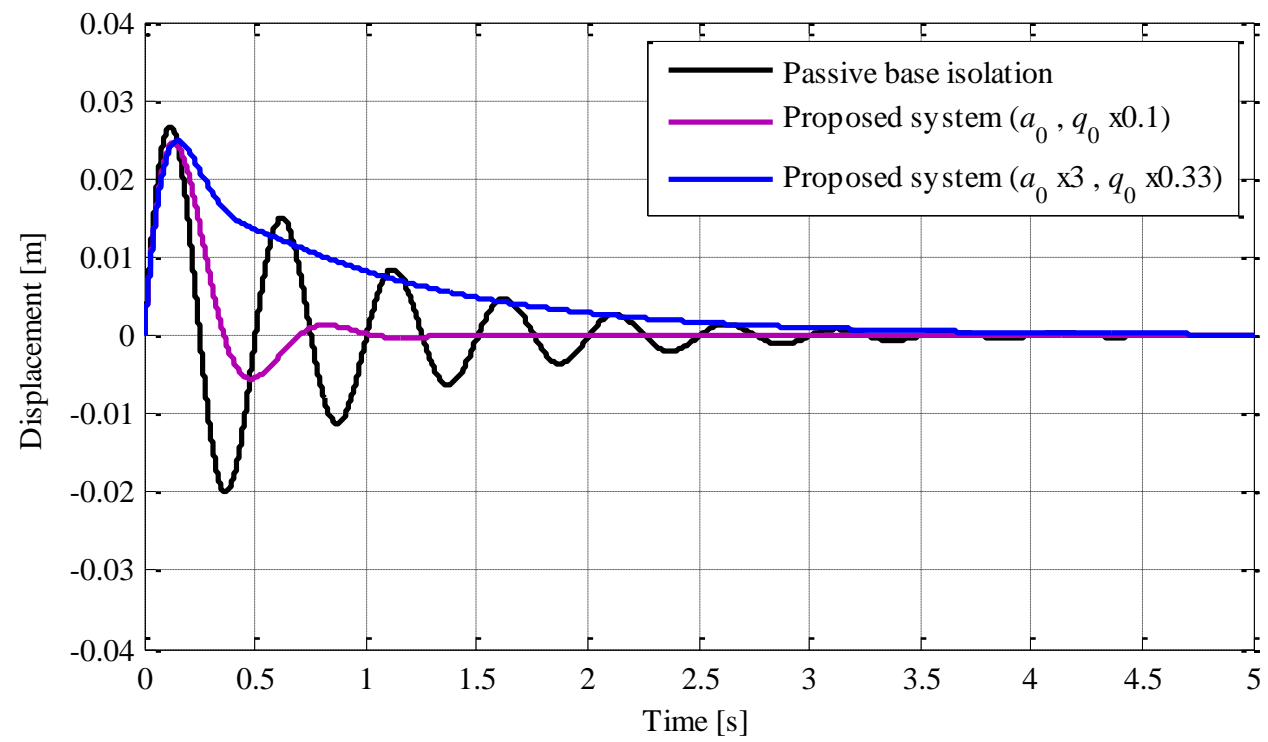

Fig. 16 Time responses of the structure for impulse disturbance. Black line shows absolute displacement of the structure model when impulse external force is input to the passive base isolation system, the other lines show the displacement when impulse external force is input to the proposed system with various values of $q$ and $a$. 


\section{6. 結 言}

電子装置を用いない新たなアクティブ免震制御機構を提案し，この機構が機能することをシミュレーション上 で確認し，また，その機能を実際の装置で再現できることを実験により実証した。 リンクの長さ比を変えること で機構の特性を変化させられることをシミュレーションにより示し，実験においても同様の傾向が見られること を確認した．さらに，スプール特性とシリンダ受圧面積のパラメータを調整することで更なる性能の向上が図れ ることをシミュレーションにより示した。今後は実験装置を大型化し，より実際に近い環境での免震性能の検証 を目指す。

\section{文献}

藤田隆史，鎌田崇義，高層建物制振用アクティブ・マスダンパの誤動作防止方法について一その 1 , マスダンパ の吸収エネルギを監視する方法一，生産研究，Vol. 46，No. 10 (1994a) pp.517-520.

藤田隆史，鎌田崇義，高層建物制振用アクティブ・マスダンパの誤動作防止方法について一その 2, センサ異常 に対する方法一，生産研究，Vol. 46, No. 10 (1994b) pp.521-524.

小鹿紀英，制振・免震構造の開発と適用の現状，日本地震工学会誌 Vol.14 (2011), pp.42-45.

斉藤大樹，耐震・免震・制震のはなし 第 2 版，日刊工業新聞 (2008).

和地天平，青木保夫，田川泰敬，梶原浩一，電子装置を用いない高信頼性油圧アクティブ免震システムの提案， Dynamics and Design Conference 講演原稿, (2012a).

和地天平，青木保夫，田川泰敬，梶原浩一，機械式制御によるフルアクティブ免震装置の開発，第 55 回自動制御 連合講演会, ROMBUNNO.2K401, (2012b).

渡辺哲巳，遠藤文明，山中昌之，勝俣英雄，蔭山満，佐野剛志，吉田修，絶対制振によるアクティブ免震手法の 実建物一の適用，日本建築学会大会学術講演梗概集, (2010).

吉田治，蔭山満，佐野剛志，遠藤文明，渡辺哲巳，勝俣英雄，スーパーアクティブ制震「ラピュタ $2 \mathrm{D} 」$, 大林組 技術研究所報, No. 74 (2010), pp. 1-8.

吉田治，蔭山満，佐野剛志，勝俣英雄，遠藤文明，渡辺哲巳，山中昌之，絶対制震理論によるアクティブ免震手 法の実建物への適用，日本機械学会論文集 C 編 Vol. 78 No.789 (2012), pp.1632-1643.

\section{References}

Fujita,T. and Kamata, T., Fault diagnosis method in active mass dampers for vibration control of tall buildings: part 1, monitoring of energy absorbing performance of mass damper, Seisan-kenkyu, Vol. 46, No. 10(1994a) pp.517-520 (in Japanese).

Fujita, T. and Kamata, T., Fault diagnosis method in active mass dampers for vibration control of tall buildings: part 2, method for sensor malfunction, Seisan-kenkyu, Vol. 46, No. 10(1994b) pp.521-524 (in Japanese).

Koshika, N., Seishin menshin kouzou no kaihatsu to tekiyou no genzyou, Bulletin of JAEE, Vol. 14(2011), pp. $42-45$ (in Japanese).

Saito, D., Taishin menshin seishin no hanashi the second edition, Nikkan Kogyo Shinbun( 2008) (in Japanese).

Wachi, T., Aoki, Y., Tagawa, Y. and Kajiwara, K., Highly reliable active hydraulic base isolation system without electric devaices, dynamics and design conference(2012a) (in Japanese).

Wachi, T., Aoki, Y., Tagawa, Y. and Kajiwara, K., Development of full active seismic isolator that uses mechanical control, the 55th Japan joint automatic control conference(2012b), ROMBUNNO.2K401 (in Japanese).

Watanabe, T., Endou H., Yamanaka, M., Katsumata, H., Kageyama, M., Sano, T. and Yoshida, O., Application of active base isolation system using absolute vibration control technology, architectural institute of Japan(2010) (in Japanese).

Yoshida, O., Kageyama, M., Sano, T., Endou H., Watanabe, T. and Katsumata, H., Super active base isolation system Laputa 2D, report of Obayashi corporation technical research institute, No. 74(2010) pp. 1- 8 (in Japanese).

Yoshida, O., Kageyama, M., Sano, T., Katsumata, H., Endou H., Watanabe, T. and Yamanaka, M., Application of active base isolation system using absolute vibration control technology, transactions of the Japan society of mechanical engineers, series C, Vol. 78, No. 789(2012) pp.1632-1643 (in Japanese). 